Case Report

\title{
Vaginal Delivery in Placental Abruption
}

Persalinan Pervaginam pada Solusio Plasenta

\author{
JM Seno Adjie', M Farid Ghazali ${ }^{2}$, Denny Khusen ${ }^{1}$ \\ ${ }^{1}$ Department of Obstetrics and Gynecology \\ Faculty of Medicine Universitas Indonesia/ \\ Dr. Cipto Mangunkusumo Hospital \\ Jakarta \\ ${ }^{2}$ Department of Obstetrics and Gynecology \\ RSUD Kerawang
}

\begin{abstract}
Objective: To describe the case of vaginal delivery in placental abruption.

Methods: A case report

Results: In the case of placental abruption, we could perform vaginal delivery.

Conclusion: The treatment of placental abruption can be vaginally or by cesarean section depending on the severity of disease, gestational age, and state of the mother and fetus.

[Indones J Obstet Gynecol 2018; 6-3: 193-197]

Keywords: IUFD, placental abruption, vaginal delivery
\end{abstract}

\begin{abstract}
Abstrak
Tujuan: Mendeskripsikan kasus persalinan pervaginam pada solusio plasenta.

Metode: Laporan kasus.

Hasil: Pada kasus solusio plasenta persalinan dapat dilakukan secara pervaginam.

Kesimpulan: Penanganan terhadap solusio plasenta dapat secara pervaginam ataupun secara seksio sesarea bergantung dari berat ringannya penyakit, usia kehamilan, serta keadaan ibu dan janin.

[Maj Obstet Ginekol Indones 2018; 6-3: 193-197]

Kata kunci: IUFD, persalinan pervaginam, solusio plasenta
\end{abstract}

\section{INTRODUCTION}

Placental abruption is the premature separation of the placenta from normal implantation in the uterus (uterine corpus) in the period more than 20 weeks of pregnancy and before the fetus delivery. ${ }^{1,2}$ Placental contains many blood vessels that allow the delivery of nutrients from mother to fetus. If the placenta separates from the normal implantation, it'll cause great bleeding. ${ }^{3-5}$

The incidence of placental abruption range from $1 \%-2 \%$ of all gestation. ${ }^{1}$ Risk of maternal mortality estimated $0.5 \%-5 \%$ and fetal mortality 20-40\%. The incidence of abruption increases parallel to increase of gestation. Bleeding of placental abruption is actually more dangerous than placenta previa because on certain cases bleeding that looked out through the vagina is not comparable, it causes placental abruption is more dangerous because in such circumstances often approximate total blood that has come out is difficult to predict, because the fetus had died and the mother is in shock condition. ${ }^{1,6-10}$

The cause of placental abruption is not known with certainty, but in severe cases correlation with chronic vascular hypertension, $15.5 \%$ accompanied by preeclampsia. Other factors are thought to play a role as a cause of placental abruption is the high level of parity and rising age of the mother, in addition relation to chorioamnionitis, premature rupture of membranes, smoking, multiple gestation, low birth weight. $3,11,12$

Symptoms and signs of placental abruption are diverse, making it difficult to enforce the diagnosis quickly. The symptom can be found as a single symptom, but more often a combination of symptoms. Placental abruption is a disease of pregnancy relatively common and can seriously harm the condition of mother. A mother who had experienced placental abruption, have a higher risk of experiencing a recurrence in 
subsequent pregnancies. Placental abruption also tends to make the morbidity and even mortality in the fetus. 3,13

The management of placental abruption is termination of pregnancy to save the life of the fetus and delivery of the placenta in order to stop the bleeding. Mode of delivery in cases of placental abruption can be vaginally or by cesarean section depending on severity of the disease, the amount of bleeding, signs of spontaneous labor or not, gestational age, and signs of fetal distress. If the fetus is still alive and term infant, but there is no sign of vaginal delivery, generally we choose delivery via emergency cesarean section. ${ }^{2}$ In a lot of bleeding immediately do resuscitation by administering blood transfusions and crystalloid fairly followed childbirth accelerated to control the bleeding and save the mother with a hope that a fetus can also be saved. Generally, the pregnancy is terminated by induction or stimulation of parturition in patients with mild or fetal death, or directly by caesarean section, in severe cases or fetal distress. ${ }^{14,15}$

\section{CASE}

Patient R, 19 years old come to the ER with referrals obstetric hemorrhage. Patients admitted to 8 months pregnant. The first day of the last menstrual period 29 November 2014, the estimated date of confinement 5 September 2015, the gestational age of 32-33 weeks and has 1 time

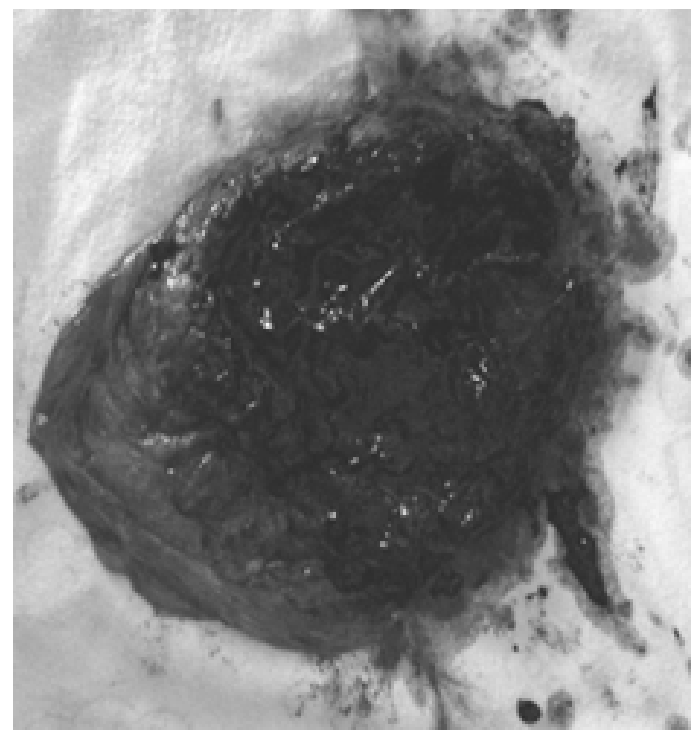

Figure 2. The placental maternal and fetal side view ultrasound examination and said the fetus in good condition. Patient undergoing antenatal examination regularly by a midwife. The patient was bleeding from one day before admission, contraction since 1 day before admission, water broke and bloody show denied. Movement of the baby has been reduced since 1 day before admission. This was her first pregnancy. Patient has been married since one year ago, and has never used contraception. History of massage was denied.

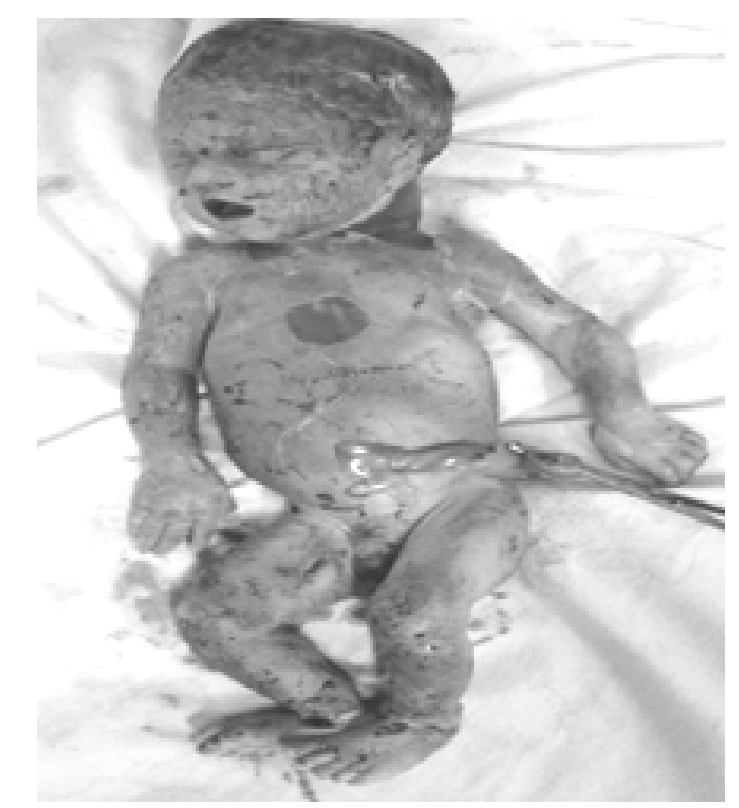

Figure 1. IUFD

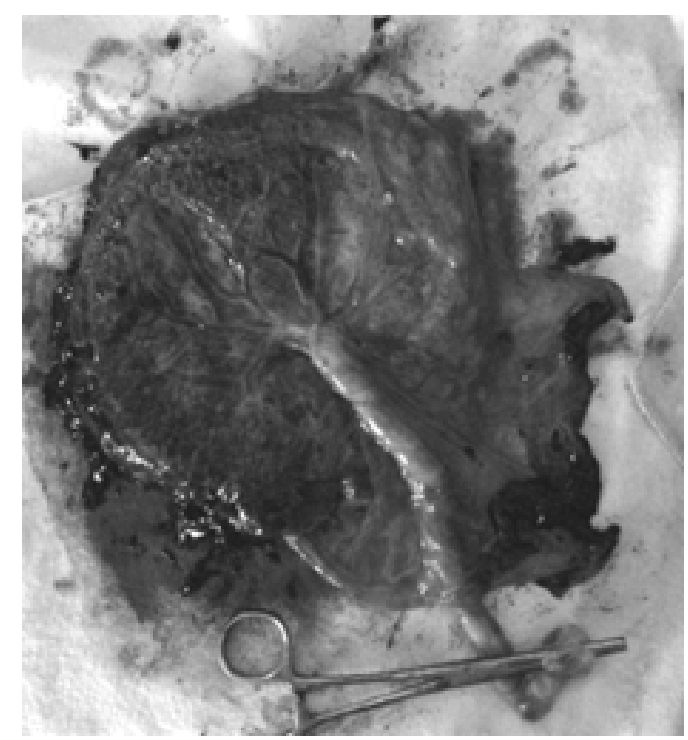


On physical examination was found moderate condition, compos mentis, hemodynamically stable, blood pressure $120 / 80 \mathrm{mmHg}$, pulse 80 $\mathrm{x} / \mathrm{min}$, respiration rate $16 \mathrm{x} / \mathrm{min}$, temperature $37^{\circ} \mathrm{C}$, and found no abnormalities in generalist status. Height of the uterine fundus was found $30 \mathrm{~cm}$, in the right location, irregular contraction, no fetal heart rate, vaginal toucher was found soft portio, thickness $1 \mathrm{~cm}$, axial direction, opening 3 $\mathrm{cm}$, head on Hodge I-II, amniotic fluid positive. Laboratory results were $\mathrm{Hb} 10.1 \mathrm{~g} / \mathrm{dl}$, Leukocytes $13,310 /$ ul platelets $155.000 / \mathrm{ul}$, rapid blood glucose $90 \mathrm{mg} / \mathrm{dl}$. There was not found fetal heart rate from US examination, and there was a sign of abruption.

The patient was planned cervical ripening with misoprostol $25 \mathrm{mcg} / 6$ hours, after 4 hours observation, it reached the $2^{\text {nd }}$ stage of labour, later born baby boy weight 1700 grams, body length 42 $\mathrm{cm}$, IUFD, placental $\pm 100 \%$, grade III maceration. (Figure 1. and 2)

\section{DISCUSSION}

The pathophysiology of placental abruption is bleeding. It may occur in the blood vessels of the placenta or uterus that forms a hematoma in the decidua, thereby the placenta pressed and eventually released. If the bleeding is only slightly, small hematoma that would only urge the placental tissue, blood circulation between the uterus and the placenta has not been disturbed, signs and symptoms were not clear. Usually the bleeding will occur continuously as the uterine muscle that has been stretched by pregnancy is not able to continue to contract to stop the bleeding. As a consequence, retroplacentalhematoma will grow large, so that partially and finally all parts of the placenta separates from the uterine wall. Most blood will enter under the membranes and penetrate the membranes into the bag. (Figure 3 ). ${ }^{3}$ However finally suspected abruption due to anaemia, tetanic contractions and ultrasound picture there were detatch.

The occurrence of placental abruption triggered by bleeding into the decidua basalis which is then split and improve thin layer attached to myometrium forming a hematoma decidua which causes the release, compression and eventual destruction of the placenta adjacent to the part. (Figure 4) Ruptured spiral decidua artery cause retroplacental hematoma which will have more bleeding, until the release of placental broader and reaches the edge of the placenta, because the uterus remains distention with their fetus, the uterus is unable to contract optimally to suppress the blood vessels. Furthermore, the blood that flows out can release the membranes. Placental abruption is the result of a process that started from a state that is capable of separating chorionic placental villi from implantation in basal decidua causing bleeding. Therefore pathophysiology relies on the etiology. ${ }^{2}$

The state of the fetus depends on the extent of the placenta detached from the uterine wall. When mostly or entirely apart, there will be anoxia resulting in fetal death. If a small portion is released, may not affect at all, or will result in fetal distress.

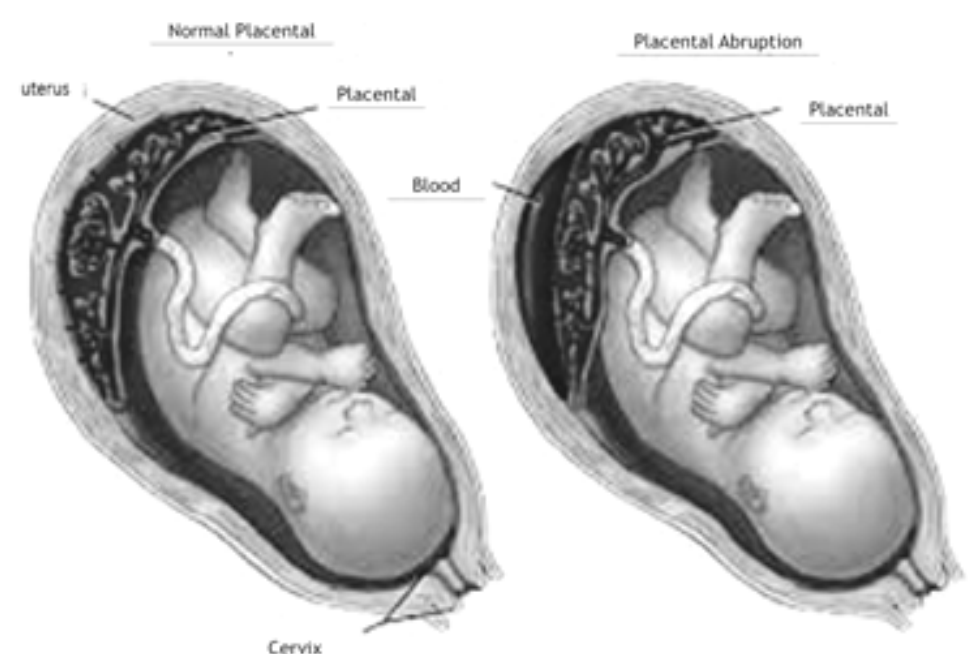

Figure 3. Differences in normal placental and placental abruption. 
Time will determine the severity of blood clotting disorders, kidney disorders, and fetal status. The longer handling placental abruption, the more severe the complication. ${ }^{3}$ In the case of fetal death in trimester 3 and immature cervix can be given misoprostol 25 ug vaginally every 6 hours or 25 mcg orally every 2 hours based on FIGO.1,2,16

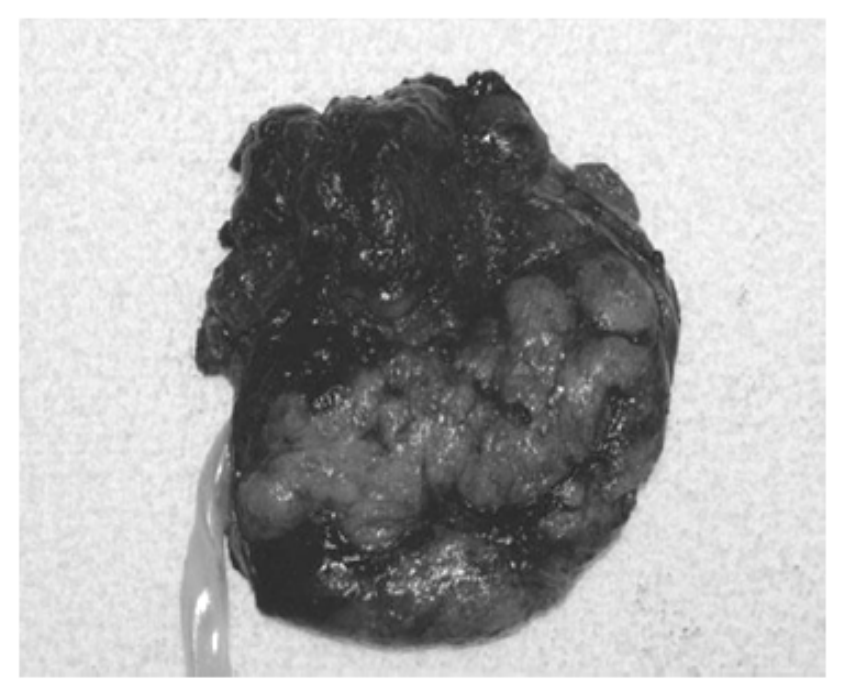

Figure 4. Overview of maternal placental abruption

In cases where there was a death of the fetus, we choose vaginal delivery unless there is heavy bleeding that is not resolved with many blood transfusions or other obstetric indications exist that require deliveries by cesarean section. Hemostatic on placental implantation site depends completely on the strength of contraction of the myometrium by pharmacologically or message that reinforced myometrial contractions and prevents heavy bleeding after childbirth although the state still coagulation disorders. ${ }^{3}$

Management abruption in a live fetus with the uterus rigid is by cesarean section but in the soft uterus may be considered to induce labor because of the possibility coagulopathy is low and the possibility of birth vaginally good, but when doing labor induction occurs hypertonus and the baby's heart rate is not good then you should followed by a cesarean section. ${ }^{1}$

According to the WHO guidelines in the event of severe haemorrhage with early signs of shock, we should take immediate delivery. If bleeding is severe with complete cervical dilation, vacuum extraction can be performed, and if the opening of the cervix is not yet complete, we can perform cesarean section. Meanwhile, when bleeding slightly depending the results of fetal heart rate, if the fetal heart rate normal, cesarean section can be performed. If the fetal heart rate absent and maternal blood pressure normal, vaginal delivery can be considered. When the fetal heart rate absent and the mother's blood pressure has a problem, we can break the membrane. ${ }^{17}$

In the above case for pregnant women with fetal IUFD, we planned to terminate the pregnancy by vaginal delivery with misoprostol.

\section{CONCLUSION}

The principle of mothers with placental abruption is to prevent maternal mortality, stop the source of the bleeding. Treatment of placental abruption varies according to case depending on the severity of disease, gestational age, as well as the state of the mother and fetus. If the fetus is still alive, term baby and there is no sign of vaginal delivery, then the selected delivery by cesarean section. While in patients with mild or fetus has died, the termination can be done by induction.

\section{REFERENCES}

1. Arias F, Daftary SN, Bhide AG. Practical guide to high risk pregnancy and delivery. Bleeding during pregnancy. $3^{\text {ed }}$. Delhi: Elsevier; 2008: 323-57.

2. Prawirohardjo S. Ilmu kebidanan. Perdarahan pada kehamilan lanjut dan persalinan. 4ed. Jakarta: PT. Bina Pustaka Sarwono Prawirohardjo; 2011: 503-13.

3. Cuningham FG, Leveno KJ, Bloom SL, Spong CY, Dashe JS, Hoffman BL,et al. Williams obstetrics. Obstetrical hemorrhage. 24ed. New York: McGraw-Hill; 2014: 793-8.

4. Macheku GS, Philemon RN, Oneko O, Mlay PS, Masenga G, et al. Frequency, risk factors and feto-maternal outcomes of abruption placentae in Northern Tanzania: a registry-based retrospective cohort study. BMC pregnancy and childbirth. 2015; 15: 242-52.

5. Patel A. Fetomaternal outcome in cases of abruption placenta. Int J Advanced in case reports. 2016; 3(1): 56-8.

6. Oyelese Y, Ananth CV. Placental abruption. Am College Obstet Gynecol 2006; 108(4): 1005-17.

7. Honda M, Matsunaga S, Era S, Takai Y, Baba K, Seki H. Intrapartum anti-disseminated intravascular coagulation therapy leading to successful vaginal delivery following intrauterine fetal death caused by placental abruption: a case report. J Med case reports. 2014; 8: 461-6.

8. Sarwar I, Abbasi Au, Islam A. Abruptio placentae and its complications at ayub teaching hospital Abbottabad. J Ayub Med Coll Abbottabad 2006; 18(1): 1-5.

9. Tikkanen M. Placental abruption: studies on incidence, risk factors and potential predictive biomarkers. Helsinki. 2008: 1-79. 
10. DeRoo L, Skjaerven R, Wilcox A, Klungsoyr K, et al. Placental abruption and long term maternal cardiovascular disease mortality: a population-based registry study in Norway and Sweden. Eur J Epidemiol. 2016; 31: 501-11.

11. Gelaye B, Sumner SJ, Mc Ritchie S, Carlson JE, Ananth CV, et al. Maternal early pregnancy serum metabolomics profile and abnormal vaginal bleeding as predictors of placental abruption: a prospective study. PLOS ONE. 2016; 11(6): e0156755-66.

12. Parker SE, Werler MM, Gissler M, Tikkanen M, Ananth CV. Placental abruption and subsequent risk of preeclampsia: a population-based case-control study. Pediatr Perinatal Epidemiol. 2015; 29(3): 211-9.
13. Ananth CV, Keyes KM, Hamilton A, Gissler M, Wu C, et al. An international contrast of rates of placental abruption: an age-period-cohort analysis. PLOS ONE. 2015; 10(5): e0125246-61.

14. Dutta DC. Textbook of obstetrics. Antepartum hemorrhage. 7ed. Delhi: Jaypee; 2013: 252-9.

15. Imanaka S,Naruse K, Akasaka J, Shigemitsu A, Iwai K, Kobayashi H. Vaginal delivery after placental abruption and intrauterine fetal death, including failed cases. Int Fed Gynecol Obstet. 2014; 126: 181-2.

16. FIGO. Recommended dosages vaginal delivery misoprostol. 2012.

17. WHO. Pelayanan kesehatan ibu di fasilitas kesehatan dasar dan rujukan. Jakarta. 2013. 